\title{
Legitimating institutional choices in the forest ownership : building acceptability for jointly owned forests
}

\section{Lähdesmäki, Merja}

2016-12

Lähdesmäki , M , Matilainen , A \& Siltaoja , M 2016, ' Legitimating institutional choices in the forest ownership : building acceptability for jointly owned forests ' , European Journal of Forest Research , vol. 135 , no. 6 , pp. 1055-1069 . https://doi.org/10.1007/s10342-016-0993-4

http://hdl.handle.net/10138/334702

https://doi.org/10.1007/s10342-016-0993-4

acceptedVersion

Downloaded from Helda, University of Helsinki institutional repository.

This is an electronic reprint of the original article.

This reprint may differ from the original in pagination and typographic detail.

Please cite the original version. 
TITLE PAGE

Legitimating institutional choices in the forest ownership - Discursive justification of jointly owned forests

Merja Lähdesmäki

University of Helsinki, Ruralia Institute

Kampusranta $9 \mathrm{C}$

60320 Seinajoki, Finland

merja.lahdesmaki@helsinki.fi

tel. +358 504151155

Anne Matilainen

University of Helsinki, Ruralia Institute

Kampusranta $9 \mathrm{C}$

60320 Seinajoki, Finland

Marjo Siltaoja

University of Jyväskylä

School of Business and Economics

P.O.Box 35

40014 University of Jyväskylä, Finland 


\title{
Legitimating institutional choices in forest ownership: Discursive justification of jointly-owned forests
}

\begin{abstract}
Recent demographic changes in the forest-owner structure are suspected to have led to the increasing number of owners with no specific objectives for their forests. In addition, the continuous fragmentation of the forest holdings has increased the threat of the passiveness related to forest management. To decrease the tendency towards passiveness, new policy tools and initiatives have been suggested. In the Finnish context, the idea of an investor-based jointly-owned forest has been introduced as facilitating the effective utilization of the forest resource. However, collective ownership has faced prejudice and scepticism among private forest owners. In order to expand, the forest owners need to see the idea of jointly-owned forests as a socially legitimate. Thus, by adopting Van Leeuwen's framework for analyzing the way discourses participate to construct legitimation for social practices, we examine how Finnish forest owners discursively legitimate their participation in jointlyowned forests. The qualitative data of the study consists of 20 in-depth interviews with private forest owners who have joined a jointly-owned forest. The results illustrate the multiple legitimation strategies used and how they contribute to renewing the identity of a forest owner. Accordingly, we suggest that the moral and emotional nature of forest ownership should be better taken into account at the policy level and in structural designs when discussing the promotion of new types of forest ownership.
\end{abstract}

Key words: Forest ownership, identity, jointly-owned forest, institutions, legitimation 


\section{Introduction}

Previous studies in northern Europe have demonstrated significant demographic changes in the forest-owner structure, which has become increasingly diverse with more non-farming, female and elderly owners. Similarly, these studies have shown that the demographic changes in the ownership structure are reflected in the values and objectives of forest owners by making them more versatile (e.g., Boon et al. 2004; Boon and Meilby 2004; Hugosson and Ingemarson 2004; Ingemarson et al. 2006; Karppinen and Tiainen 2010; Kuuluvainen et al. 1996). These changes are sometimes considered to entail some threats, especially from the viewpoint of forestry, as they are suspected of leading to the increasing number of owners who have no specific objectives for their forests (e.g., Butler and Leatherberry 2004; Leppänen 2010). This has further raised concern over whether the forest-owning generation is becoming more passive and indifferent in their forest management activities. At the national level, an increasing number of indifferent and passive forest owners is therefore often seen challenge to policy makers (Boon et al 2004). Especially in the countries, in which forestry has an important role in national economics and the proportion of private forest owners is high, the changes in the forest ownership structure have been seen as a potential risk in terms of profitable forestry (Korhonen 2010).

Finland is a country that fits in with the description above. At the same time, the forest holdings of new forest owners are more and more fragmented. The fragmentation has been an on-going process typically stemming from the division of forest holdings equally between the heirs during the distribution of the estate. For example, approximately 5000 new forest holdings were established between 2006 and 2011 in Finland (Leppänen and Sevola 2014). Fragmentation of forest holdings can further increase or enhance the passiveness of forest management as it has been suggested that owners of larger holdings are more active managers than the owners of smaller parcels, whether the goal is timber production or natural protection (e.g., Best 2004). Because of this, various policy initiatives, for example tax reliefs in cases where the forest is not divided between heirs, have been considered in order to enlarge the size of the holdings (Ministry of Agriculture and Forestry 2012) and, by implication, increase the economic benefits of forest management deriving from the larger units.

As a potential means of preventing fragmentation and improving the effective utilization of the forest resource, the Finnish forestry has introduced the idea of an investor-based jointly-owned forest (JOF). A JOF can be defined as an area of combined holdings intended for the practice of sustainable forestry for the benefit of the shareholders. The inherent aim of JOFs is to make forest management easier for the forest owners 
and simultaneously create more efficient and larger areas in order to increase the profitability of the forest economy (Korhonen, 2010). The establishment of JOFs alters the core idea of ownership as it diminishes the individual forest owner's ability to control his/her holdings (author identification removed). As a shareholder in a JOF, the forest owner transfers the practical management decisions, including the wood trade, to a selected group of trustees (Korhonen 2010; Havia 2012). As compensation for handing out the ultimate control over forest management, the shareholders are entitled to a stipulated revenue from the JOF's annual return.

Despite the policy support for the formation of JOFs, for example, through tax concessions, JOFs have, however, raised some prejudices and scepticism among private forest owners by challenging some traditionally strongly held values, rights and obligations related to private forest ownership, like the right to control one's own forest property (author identification removed). Thus we argue that the idea of a JOF requires social legitimacy in order to get support among the forest owners, i.e., it needs to meet the conception of socially acceptable behaviour (see Meyer and Rowan 1977; Suchman, 1995; Suddaby and Greenwood 2005; Zimmerman and Zeitz 2002). If successful, the acceptance of a new institutional form of forest ownership can be considered as a product of discursive practices through which judgements regarding the propriety and validity of the entity are made (cf. Bitektine and Haack 2015). Accordingly, after the establishment of a new macro-level policy such as a JOF which is not yet fully institutionalized, i.e. widely accepted, those for whom the policy is intended, need to construct "legitimating accounts" (Creed, Scully and Austin 2002) that bring out the appropriateness of the new practices. If this does not take place, institutional changes are not likely to achieve widespread recognition and stability (Bitektine and Haack 2015; Steffek 2009).

In this paper, we examine the discursive legitimation accounts of private forest owners who describe their personal decision to become a JOF shareholder. The legitimation process is approached similarly to Van Leeuwen (2007, p. 94) as an answer to the spoken or unspoken question 'Why should we do this?' or 'Why should we do this in this way?' In other words, legitimation is understood in this paper as a more or less deliberate discursive process by which speakers justify JOFs by making discursive judgements regarding their propriety and validity as a form of forest ownership (see Bitektine and Haack 2015; Reyes 2011; Suddaby and Greenwood 2005). Accordingly, this paper aims to answer the following research question: What kind of discursive legitimation strategies do forest owners use in order to justify a JOF as the socially accepted form of forest ownership and how do they used them? Results of our study add to the understanding of the very nature and essence of JOFs as forest-owning practice from the perspective of private forest owners. Furthermore, based 
on the results, we suggest that the moral and emotional nature of forest ownership should be better taken into account at the policy level and in structural designs when discussing the promotion of the concept of JOFs to enhance the formation of new establishments.

\section{Theoretical framework}

\section{Jointly-owned forests as a forest owning institution}

The majority of the Finnish forests (60 per cent) are owned by private non-industrial forest owners who together own approximately 12 million hectares of the forest area (Suomen Metsät 2012). There are some 632,000 individual family forest owners in Finland which means that nearly 14 percent of Finns are forest owners (ibid). At the moment, there are almost 300 JOFs in Finland - constituting approximately 4.5 per cent of all the nonindustrial, privately-owned forest area (Matilainen 2009). During 2007-2013, 120 new JOFs were established (Leppänen and Torvelainen 2015). Even though the discussion of JOFs has accelerated during the last few years, the phenomenon itself has its roots in the history of Finnish forest ownership. The first JOFs were established in Finland in the late 19th century, primarily by the authoritative orders. For the time being, establishing JOFs contributed to the top-down approach to redistribution and reallocation of state or common land holdings — and thus to the enhancement of rural living conditions. A particularly active phase in the establishment of administrative JOFs took place after the Second World War when a number of JOFs were established as a part of the Karelian evacuee resettlement policy. However, a significant recent landmark occurred with the legislative reform in 2003 which enabled the establishment of a new sort of JOF, joining private forest holdings into larger units based on a common, voluntary agreement between forest owners (Havia 2012). In other words, the reform made it easier for private forest owners, family members or investors, to set up a JOF, and this was also reflected in the number of new establishments. This change was also supported by taxation policy. Although new JOFs are mainly minor joint-ownerships between family members, there is also increasing interest in the establishment of investor-based JOFs, which are the focus of this paper.

Private forest ownership can be considered as an institution which has provided particular role identities, organizational forms and relationships between various actors. Indeed, previous studies have shown that a forest can contribute to the identity of the family that owns and manages it by being a symbol that can endure beyond the lifespan of a single generation (Bliss and Martin 1988). Altering institutions is not, therefore, 
an easy task, since they consist of social structures that have achieved a high level of resistance (Scott 1995). This resistance is further strengthened by the fact that institutions in societies are linked to each other. For example, the regulatory processes that define and determine ownership also have an influence on the societal valuation and norms concerning ownership - what is considered a normal and appropriate form of it. One of the reasons for institutional changes being slow is then found in their connections with societal norms and values which can be rather resistant to change (Scott 1995).

A fundamental concept of the institutional theory is legitimacy, which is sometimes seen as virtually synonymous with institutionalization. Legitimacy is the perception or belief that an institution or social arrangement is desirable and appropriate within some socially constructed system of norms, values, beliefs and definitions (Suchman 1995). Legitimacy is thus not defined solely by what is legal or illegal (Dowling and Pfeffer 1975) but more in terms of acceptability or acceptance, taken-for-grantedness, reasonableness, appropriateness, and congruence (Deephouse and Carter 2005). Legitimacy is further a resource that secures the achievement of other resources (Zimmerman and Zeit 2002). It has also been found to be a crucial resource for the spread of business models and programs (ibid.) as well as different types of ownership (Thomsen 2006).

More specifically then, JOFs need to be considered a legitimate type of ownership to attract potential owners and societal resources that support its spread and existence. JOFs represent an attempt to alter the norms of private forest ownership by legally setting required premises as well as the processual and structural organization of forest ownership. In other words, in the establishment of JOFs two or more forest holdings are incorporated into a common "new" forest unit. In order to be legally competent, a JOF needs a treaty signed by all the partners, the assessment of shares for each partner, the land division proceedings required, common regulations, an administrative board whose members are voted for by the shareholders and an annual strategy and budget. The administrative board is responsible for the practical forest management decisions which are, however, guided by a forest management plan accepted by the shareholders (Havia 2012, pp 10-19). Thus, the forest area of a JOF is jointly managed and a single shareholder does not have the right to carry out any independent forestry activities. The shareholders have the right to vote on the common JOF decisions as well as the right to receive a surplus ratio determined in relation to the value of each owner's forest estate incorporated into the JOF (Act on Jointly Owned Forests 2003.)

The official national forest policy discourse often promotes the new JOFs through the ideas of unit cost declines and continuous revenues. Furthermore, since JOFs are considered to prevent the fragmentation 
of holdings, there is a clear political consensus on promoting the establishment of new JOFs and the enlargement of the old ones (e.g., Ministry of Agriculture and Forestry 2012). Still, joining a JOF is not usually an easy decision, as owning a forest often involves certain sentimental and/or recreational values that can be endangered by becoming a JOF shareholder (author identification removed; Rämö and Tilli 2007). Furthermore, the knowledge of JOFs among private forest owners can be quite slight or even misinformed, which further decreases their willingness to participate in a JOF (ibid.).

\section{Discursive legitimation to build social acceptance}

Social legitimacy is considered vital for the widespread diffusion of new ideas and social arrangements. In this study, we take a processual perspective and examine the means designed to build legitimacy among the forest owners. Thus, we focus on the discursive legitimation efforts of JOFs. Legitimation is virtually always textual and symbolic (Martin Rojo and Van Dijk 1997), which underlines the importance of focusing on its discursive underpinnings. For example, although JOFs would not yet enjoy widespread legitimacy in Finland, there is likely to exist discursive activity that aims towards their legitimation i.e., justification, particularly among the forest owners who judge the appropriateness of JOFs as a form of ownership. Although legitimation efforts do not necessarily lead to widespread legitimacy either, they can be considered vital for the construction of clear meanings that later may result in a positive appeal (legitimacy) (cf. Verge and Wry 2014).

We apply the discursive approach to legitimation developed by Van Leeuwen (2007) to examine in detail the private forest owners' means of legitimizing participation in a JOF. This discursive approach to legitimation is a theoretical-methodological framework that has previously been successfully applied in the organizational research examining, corporate mergers (e.g., Vaara et al. 2006; Erkama and Vaara 2010), the euro crisis (Vaara 2014), cartel agreements (author identification removed) and corporate responsibility (author identification removed). In this approach, legitimation means the creation of a sense of positive, beneficial, ethical, understandable, necessary, or otherwise acceptable action in a specific setting (Van

Dijk, 1998; Van Leeuwen and Wodak, 1999). According to Van Leuuwen (2007), there are four major legitimation strategies to be recognized - authorization, rationalization, moral evaluation and mythopoesis.

Authorization is legitimation by reference to someone with vested authority due to their status or role in a certain institution or their organizational expertise (Van Leeuwen 2007). For example, in the forest- 
owership context, the forest advisers can often influence the decision-making process of forest owners greatly, especially if they consider their own forestry competence relatively low (Follo 2011; Hujala et al. 2007). Indeed, the contemporary structural changes in forest ownership are sometimes suspected of increasing the number of less competent owners, which may further strengthen the authority of forest advisers when legitimizing forestry decisions. In addition to influential persons, authorization can also be based on impersonal authority, like law, traditions and customs (Van Leeuwen 2007). Traditions can often play an important role in forestry decisions (Lidestav 1998). Thus, decisions can, for example, be legitimized by referring to family traditions as an inherited forest holding has been seen as creating emotional restrictions on the autonomous control of the forest (author identification removed). Furthermore, authorization can also be accomplished by referring simply to conformity, resting on the principle that something is constructed as legitimate by claiming that "everybody is doing it" or “everybody says so" (Van Leeuwen 2007).

Legitimation through moral evaluation is based on moral values (Van Leeuwen 2007), which are an integral part of any ethical process evaluating what is right, just and fair. It has been shown that moral argument is often used in relation to forest management decisions. For example, the drive to maximize timber production through intensive management is sometimes legitimized by referring to a moral obligation to utilize the natural resources entrusted to the forest owner (e.g., Bliss and Martin 1988). Similarly, the forest owners' willingness to manage the forest in an environmentally sustainable way has been justified by referring to a moral value (Lönnstedt 2012). More generally, it has been suggested that forest owners are more likely to engage in forest management when they believe that they are fulfilling a moral norm (Domínguez and Shannon 2011).

In rationalization, legitimation is grounded either on some kind of truth, on 'the way things are', or by reference to their goals, uses and effects (Van Leeuwen 2007). Forest management decisions are commonly legitimized by reference to instrumental rationalization, particularly by emphasizing the benefits of various silvicultural practices. For example, forest-owner typologies are often constructed on the basis of the owners' ideas of the benefits gained from the forests and ownership. Thus, a forest owner described as an 'investor' is considered to be driven in his/her forest management by economic benefits, while those who emphasize the generation of non-timber outputs in their management are said to be concerned with intangible benefits (see Ní Dhubháin et al. 2007). Similarly, the passiveness towards forest management can also be justified through benefits by stating that for passive forest owners, the primary benefit comes from the satisfaction of owning forest land (Kline et al. 2000). Furthermore, their willingness to participate in 
programmes aimed at enhancing conservation of forest biodiversity is often examined through instrumental rationalization (e.g. Horne 2006; Kilgore et al. 2007).

The fourth legitimation strategy is called mythopoesis (van Leeuwen, 2007) or narrativization (see Vaara et al. 2006), i.e., legitimation achieved through the telling of stories. In moral tales, the protagonist engages in socially legitimate practices resulting in positive consequences, whereas in cautionary tales, the protagonist engages in socially deviant behavior that results in an unhappy ending (Van Leeuwen and Wodak 1999). However, while one must emphasize that employing these strategies does not necessarily mean that it is exactly the way things have/will happen, they should be understood as ways to justify actions in given situations.

\section{Material and methods}

As in this study we wanted to find out how forest owners legitimate their "untraditional" solution (i.e. participating in a JOF) and motives to change their current ownership form - instead of keeping the traditional forest owing (i.e. not participating in a JOF) - the data was gathered among those forest owners who already were members in a JOF. Accordingly, the empirical data of this study consists of interviews with 20 private forest owners who all had joint interest in the same investor-based JOF. ${ }^{1}$ The research interviews in this study can be characterized as being semi-structured and in-depth in nature (Legard et al. 2003). Thus, before the first interview took place, we had prepared a list of broad themes that we wanted to discuss with each forest owner. These themes included a few more specific questions to prompt the discussion if needed and to obtain deeper understanding of each theme (ibid.). The interviews dealt with themes such as personal forest-owning history, the motivation for becoming a JOF shareholder, experiences of the JOF establishment process and the operation of the JOF (see Table 1). In other words, we saw the interviews as conversations with a structure that was flexible enough to permit topics to be covered in their 'natural' order with enough room for us to be responsive to the issues raised by the forest owners (Legard et al. 2003). The interviews were conducted between October

\footnotetext{
${ }^{1}$ The JOF, consisting of 85 partners, was established in 2011. The forest area was approximately 1400 hectares. In general, the sizes of the Finnish JOFs vary from approximately those under 20 hectares to 90000 hectares (Matilainen 2009). In 2015, the average size of JOFs in Finland was 1874 hectares (Metsäkeskus 2015).
} 
2012 and August 2013 in Finnish by the authors. All the interviews, the length of which varied from 30 minutes to 90 minutes, were recorded and transcribed verbatim.

\section{INSERT TABLE 1 HERE}

The selection of the forest owners interviewed was done by applying the purposeful sampling method in order to ensure informative and rich but still manageable data (Patton 2002). Accordingly, while the interviewees were selected from the shareholder contact list, certain criteria were used to ensure that the sample was as diverse as possible in the boundaries of defined population (Ritchie et al. 2003). Thus, we made sure that the empirical data consisted of both those owners living near the JOF as well as those living in other regions (see Table 2). Similarly, we paid attention to the age structure of the interviewees as we wanted forest owners from different age-groups to be involved in the study. Another criteria we used to increase the variation in the data was the way of becoming a forest owner (inheritance/purchase). Finally, we also paid attention to the size of the forest invested in the JOF which varied from three to 70 hectares. Common to the majority (15 forest owners) was that they had invested only a portion of their forests in the JOF, keeping some areas under their own control. It should be noted that by setting these criteria our idea was not to compare forest owners or to foster quantitative representativeness but to obtain the variation in the data (see Patton 2002). The variation was sought by using the mentioned criteria as it can be assumed that these background variables influence the forest owners' values (e.g., Boon et al. 2004; Boon and Meilby 2004; Hugosson and Ingemarson 2004; Karppinen and Tiainen 2010) and consequently their forest-related decisions.

\section{INSERT TABLE 2 HERE}

The data analysis method applied in this study was discourse analysis which examines how social reality is created by historically and contextually situated discourses (e.g. Alvesson and Kärreman, 2000; Phillips and Hardy 2002). Discourse analysis focuses on how and why the social world comes to have the meaning(s) that it does (Phillips and Hardy 2002). Thus, a discursive perspective means that legitimacy is build, in the course of time, through the discussion, meaning-making and debate (discourse), regarding the appropriateness of institutions and social entities. We therefore study how the legitimation of a JOF is represented through various discursive moves. Our approach to discourse analysis was abductive as the analysis involved constant movement between theory and empirical data. Thus, the classification of van Leeuwen's discursive strategies 
provided the categorization framework, through which the empirical data was reviewed for qualitative content. Our focus on van Leeuwen's theory then lets us to examine how JOFs are intricately related and legitimized in discourse.

Accordingly, we started the analysis by reading through the interview transcripts several times in order to distinguish those excerpts in which the owners aimed to explicitly justify their own participation in the JOF. In this phase, we considered the general organization of the data more than distinguishing distinct legitimation resources as such. After this phase, the interview excerpts were read more in detail in relation to van Leeuwen's theoretical model. Therefore, in the analysis, the theory and data iteratively discussed with each other. We paid close attention to the phrases, storylines and words used by the forest owners when they justified their participation in the JOF. We thus identified references to expertise, moral values, goals and benefits in order to divide the material into the categories of authorization, moralization and rationalization. We also paid attention to the narrative aspects, i.e., the storyline of legitimation accounts. We then analysed each legitimation strategy more in detail to find out how they were constructed by the forest owners, i.e., what kind of discursive resources were used in each category. The utilization of strategies partly overlaps, but this has been found to be a commonplace in the case of discursive legitimation (e.g., Vaara et al. 2006; van Leeuwen 2007). For this reason, we do not present narrativization as a separate legitimation strategy in the results as it was closely intertwined with the three other strategies, and as such, a natural way for the forest owners to articulate their reason for participating in the JOF.

In order to enhance the credibility and trustworthiness of the data analysis, a triangulation method between the researchers was used. This means that the analysis of the data was done independently and iteratively by the first two authors of the paper after which the interpretations were compared and the possible differences discussed jointly until a consensus was reached. Thus, in cases of disagreement, the data was jointly reanalysed until a shared interpretation was reached. Although rather laborious, this way of utilising analyst triangulation is often considered to increase the credibility of the research (Eisenhardt 1989; Patton 2002). Furthermore, to ensure the transparency of the interpretation of the data, some quotes from the original interviews were translated into English and included in the Results -chapter.

\section{Results}


This section introduces the discursive legitimation strategies justifying JOFs in the private forest-owner context. It should be noted that in their attempt to legitimize their decision to join the JOF, the private forest owners usually used more than one legitimization strategy. Thus, the strategies are not exclusive but mutually reinforcing as well as somewhat overlapping.

\section{Authorization: referring to expertise}

An important means by which some of the forest owners legitimized participation in the JOF was to refer to their own personal authority resulting from their role as forest owners - thus representing themselves as experts in the field. Accordingly, they stated that because of their histories as owners, they had the necessary knowledge to make the best decisions concerning their holdings. Still, they usually provided some additional arguments to further reinforce their expertise in JOFs. For example, some emphasized that even though the idea of an investor-based JOF is new in their own area, they have been able to closely monitor the operation of a JOF that has been established for relocated Karelian evacuees in the area since the Second World War. In this manner, the forest owners constructed themselves as familiar with the basic idea of joint ownership in the forest context and therefore qualified to make judgements concerning its functionality and acceptability (cf. Hutchby 2001).Thus they also highlighted their own identity as an informed forest owner. Furthermore, by referring to their personal experiences or expertise, they normalized JOFs as a practice (cf. Vaara et al. 2006) in the sense that, according to their statements, there is nothing particularly novel or suspicious in their operation as the following interview citation illustrates:

I didn't have any doubts about the jointly-owned forest because there are quite a lot of shares of another kind of jointly-owned forest in the area. It was established for the Karelian evacuees after the war and I have been watching its operation, so I have a fairly good idea of the way jointly-owned forests operate. (Int. 7)

They also supported their personal authority with references to a well-known societal authority, the media. This type of legitimation mingled with rationalization. The interviewees regularly highlighted numerical information in the newspapers as an evidence of the successful operation of JOFs. At the same time, the forest owners themselves appear as rational actors; despite the innovative nature of investor-based JOFs, they have not rushed into joint ownership without actively gathering information on its operation, as the following interview citation shows: 
I have read in newspapers that there are large jointly-owned forests in Northern Finland and they are operating just splendidly. They have their own employees and their forest area covers tens of thousands of hectares. (Int. 12)

More institutionalized expert voices were also used to justify their participation in the JOF. The authority of forest advisers, especially forest management associations, was highlighted. It should be noted however that whether or not advisers were used as an authoritative resource in the legitimation process seemed to be dependent on the social proximity between the forest owners and advisors. In other words, it was more often trust in a person and his/her authority, not the institution as such, which provided a resource for the legitimation of the JOF participation. This observation strengthens the previous research which has highlighted the importance of personal trust and communication between forest owners and experts in the decision-making processes of private forest owners (e.g., Hujala and Tikkanen 2008). The following interview citation shows how the forest owner evokes the authoritative role of a familiar forest advisor who is backing the idea of JOF participation:

I have often sought help from the forest management association. I have a friend working there and I talked with him and he considered a jointly-owned forest as a sensible choice for forest owning. (Int. 9)

The role of the municipality in the legitimation process was also crucial. For many forest owners, the fact that the municipality took part in the JOF had a crucial positive influence on their own decision-making. Accordingly, they constructed the municipality as an authority in the legitimation of the JOF by highlighting the credibility, security and sustainability that it is considered to bring to the establishment and its management. While almost a third of the forest area in the JOF was invested in by the municipality, it was considered to have a strong interest, as well as economic and human resources, in monitoring the fairness and effectiveness of the operation for the common good. The following interview citation illustrates the authoritative status produced for the legitimization of the municipality participation in the JOF:

It certainly produces a feeling of security, or at least I think so, when there is one large owner like the municipality involved in the JOF. It has an interest in seeing that everything is properly managed. And they'll have the resources and skills to interfere in things if they want to. Well, 
yes, it'll bring along... at least I reckon that the JOF is a safe way to own forest because the municipality is also involved. (Int. 18)

Finally, JOFs were also legitimated by references to the authority of tradition. According to Van Leeuwen (2007), legitimation through tradition implicitly or explicitly answers the "why" question by justifying it as a conventional way to behave. The forest owners strongly appreciated the idea of leaving the forest holding to their children as a legacy — a tradition that was thought to affect their behavior as forest owners considerably. For example, even though some of the interviewees perceived forest ownership as a "burden", they were still reluctant to sell their holdings on the open market as they did not want to break the tradition of forest ownership in the family. For them, the JOF was considered to provide a worthy and potential option for the idea of selling, and consequently to honor the tradition of maintaining forest ownership in the family. Through the participation in the JOF, the forest owners also set out to provide their children, who lived in other parts of the country, with an emotional link to the geographical family home. Thus, legitimation by reference to the authority of tradition was often also mixed with moralization as it emphasized the importance of valuing one's family roots. Indeed, the idea of a forest being constructed as an intergenerational link between the owner and his/her children demonstrates plainly that forest-related decision-making is often strongly affected by various emotional factors that distinguish the decision-making process from a purely technical exercise (see author identification removed; Tikkanen et al. 2006), as the following interview citation illustrates:

I just wish that my children and grandchildren would have some kind of link to this area so that they would know roughly speaking where they come from. Somehow you wish that such a link would remain and joining the JOF is perhaps one way to try to maintain it. (Int. 20)

\section{Moralization: referring to the sense responsibility}

The forest owners also aimed to legitimize JOFs by appealing to the emotions, particularly the sense of responsibility. Accordingly, the forest owners highlighted the importance of taking good care of one's forest property, which they consider as their moral responsibility. They thus draw upon the idea of a "good forest owner" who takes part in the JOF in order to make sure that the forests are managed in the best possible way to maintain effective wood production. Accordingly, it was emphasized that the forests in a JOF are managed in a professional manner by skilled and experienced people. The idea of a good forest owner identity was further 
reinforced by a negative representation of those owners who disregard their management responsibilities, for example, by neglecting thinning and seedling care, and thus let the forest property deteriorate as a result of their inactivity. The negative representation of other, more passive forest owners, allows the forest owners to create two sides of the process of JOF participation, in which the forest owner is in the 'us-group' and passive forest owners constitute the 'them-group' (Reyes 2011). For example, some saw urban forest owners in a negative, passive light in order to emphasize the moral value of their own decision to take part in the JOF, as the following interview excerpt illustrates:

Now, after joining the JOF, I know for sure that the forest is well taken care of. That was an important thing for us since if you own something, you also have the responsibility to take care of it. The idea that a forest is left without forest management activities, like some urban forest owners living in Helsinki area often do, is totally strange to me. So I would recommend, just for the sake of the forest, that it should be owned by someone who knows how to take care of it. (Int. 5)

It was also highlighted that a good forest owner anticipates the potential threats in the future and takes necessary actions in the present. This kind of justification can also be called 'legitimization through a hypothetical future', where an event or practice is justified by referring to a potential threat that requires present action (Reyes 2011). For example, even though the forests have always been well taken care of, this might not be the case in the future since the future forest-owner generations were sometimes thought to be rather alienated from forest management. Similarly, ageing and moving far away from the forest were seen potential reasons for not being able to manage it any more, thus forcing a good owner to deliberate on different options to secure the maintenance of his/her forests. From the moral point of view then, the interviewees argued that JOFs present a means to maintain a good forest-owner identity in a situation where the future well-being of the forest is somehow jeopardized. The following interview citation comes from a forest owner who has actively taken care of his forests but feels that his high age will soon prevent any forest management. In the citation, the forest owner expresses his worry that the forest would not be properly managed by himself (as he is getting older) or especially in the future by his children. Accordingly, the participation in the JOF provided him with the means to maintain the good forest owner identity and continue the forest management according to the forest management recommendations. 
An important thing was that the forest be well managed. Even though it's not a very large area, I wouldn't like to leave it without proper management just because of my own carelessness. So, in our case, the JOF provided the best possible solution for the forest ownership because neither of our children is able to take care of it. (Int. 14)

To a certain extent, moralization as a discursive legitimation strategy reflects the national, macro-level forest policy objectives as it emphasizes the idea of maintaining the forest's economic productivity in the best possible way (cf. Rantala and Brimmer 2003). Still, it should be understood that the moral responsibility for minding the forest was also strongly related to idea of taking care of the well-being of the next forest-owner generation. For example, the JOF was constructed as an ideal solution for maintaining equality between one's children in the distribution of the estate without further splitting the forest into smaller, economically less profitable units. In addition to wanting to treat their children fairly during the distribution of estate, the owners also wanted the forest legacy not to become a burden to their children. In other words, as some knew that their children were not interested in forest management at all, they wanted to provide their children with as effortless a way of forest ownership as possible through the JOF. In this manner, the forest owners highlighted that joining a JOF is not just about the moral responsibilities towards the forest, but also towards one's heirs. This kind of legitimation was often represented through narrativization with a cautionary nature, as the following interview citation illustrates. The forest owner justifies JOFs by constructing himself as a good parent who makes the decision to join the JOF in order to avoid complicating his children's future:

Without the JOF, we would have been forced to think about selling the forest. We didn't want to leave the forest as a burden to our children because after us, there would have been five owners to make decisions and that would have complicated things. And I asked my wife how she felt about joining the JOF and she agreed on that right away and has never questioned the decision. Well, neither of us have never questioned the decision to join the JOF. (Int. 18)

\section{Rationalization: seeking efficiency and benefits}

It was also very common for the forest owners to legitimize participation in the JOF by using rational arguments. Legitimation through rationalization highlights the idea that the loss of control over one's forest area is well compensated and at the end joining the JOF will produce more benefits than conventional private forest 
ownership would. Accordingly, one means to rationalize JOF participation was to highlight the instrumental benefits inherent in its operation. Still, it is important to note that the benefits used to justify participation were not just economic ones (productivity) as the interviewees also highlighted the benefits the JOF brings by making their personal lives as forest owners easier.

Economic benefits were constructed by emphasizing the rationality aspects in the context of the wood trade. Economic argument rarely appeared as a sole legitimation strategy in the interviews, but was most often combined with other legitimating accounts. For example, a forest owner argued that "because of the JOF, the negotiations with large wood buyers are more equal" (a moral issue) which may result in a "better price for wood" (produces rational outcomes). Similarly, in the following interview quote, the forest owner combines the strategies of narrativization with rationalization in the sense that he produces a narrative in which he constructs himself as a protagonist who, after being betrayed in wood trade, becomes enlightened enough to join the JOF in order to prevent similar malpractice occurring again:

Nowadays selling wood is a rather risky business for an individual forest owner since large industry will not hesitate to cheat those who don't understand enough about the wood trade. I have rather bitter experiences myself of dealing with a large wood business. They did such a poor job in one of my forest areas, it was practically ruined. Those large businesses are only interested in producing as much profit for their shareholders; they are trying to do everything as cheaply as possible. (Int. 4)

Even though the economic benefits were usually appreciated at the individual level, there were also some forest owners who emphasized the benefits of the JOFs at the societal level more generally. In other words, their arguments reflected the national discourse that constructs the JOFs as a potential means to prevent forest holding fragmentation, and thus increase economic benefits through more effective wood trade. The following interview citation exemplifies, in the form of narrativization, how the behaviour of the protagonist (i.e., the forest owner's decision to join the JOF) results in positive consequences (decrease in fragmentation, leading to national economic benefits):

In principle, I believe in this idea and hope that there are more and more JOFs established because of the fragmentation of the forest areas. Establishing JOFs would make forestry more efficient. The whole nation is losing money when the forests are not managed well, not 
harvested in time. Nobody will win in that. So it is for the good of us all if the forests are managed in the best possible way. (Int. 7)

It should be noted that even though economic ownership motives are often highly valued by non-industrial private forest owners (Hänninen et al. 2011, Ní Dhubháin et al. 2007), the forest owners very seldom used any profit maximization related arguments to justify JOFs. On the contrary, they acknowledged that participation in a JOF may not suit those looking for "an easy way to make a lot of money". Indeed, within a JOF, even though the wood price may be good and one could sell at a good profit, the benefits will be jointly distributed. For example, some interviewees highlighted that in the short term they would make more money just by clear cutting their forest areas. However, there would then be no any income from the forest holding for centuries and the forest owner would be responsible for regenerating and managing the area, which would also generate some cost. Thus, continual and annual revenue was more emphasized in the legitimation process with the idea of ease and manageability of ownership. In the following quote, the forest owner justifies his participation in the JOF by bringing out the ease of the ownership (explicitly meaning no need to take care of forest regeneration or taxrelated duties) as well as the idea of continuous revenue:

My aim is that forest ownership would somewhat increase my outcome and that income is taxfree in the JOF. And I don't have to think about the costs that are needed for forest regeneration and everything, so in this sense, forest owning is much easier for me. The JOF brings some annual income; it's kind of a small pension for the future. (Int. 9)

As illustrated in the example above, even though leaning on economic benefits was quite common among the interviewees when describing and justifying JOFs, the discursive rationalization was also centred on the personal benefits of JOFs since they make life as a forest owner easier. Private forest ownership was generally considered as a time-consuming commitment and JOFs were produced as a rational way to lessen these commitments. Accordingly, it was emphasized that participation in the JOF has simplified the life of forest owners by transforming their identity more into that of a shareholder. The following example portrays JOFs as a smooth and efficient solution to the concerns of ownership:

Of course it's important that you don't have worry about the forest any more. It's like buying some stocks and putting them in the bank vault and then just reading how valuable they are in 
the newspapers. This ease is the main thing; it's like owning stocks. You don't have to do anything if you don't want to; maybe it captures the JOF best. (Int. 5)

\section{Discussion}

This study demonstrated, by adopting van Leeuwen's (1997) theoretical model on discursive legitimation, what kind of discursive strategies private forest owners use to justify a new institutional form of forest ownership, the jointly-owned forest. The results show how legitimation through authorization, moralization and rationalization are accomplished in the context of jointly-owned forest, thus enabling us also to better understand the argument for the decision to become a JOF shareholder. In addition, the results verify that the various legitimation strategies in the JOF context were often intermingled and intertwined with each other, which also reflects the challenging nature of the decision-making process.

The following table (Table 3) summarizes the main results of this study by presenting the way each of the three legitimation strategies are discursively constructed and the main reason why each can be considered effective in legitimizing the idea of JOFs among private forest owners.

\section{INSERT TABLE 3 HERE}

Even though previous research on discursive legitimation strategies has acknowledged the overlapping and inclusive nature of the strategies (e.g., Vaara et al. 2006), it is interesting to notice how strongly moralization is linked with the rational legitimation of JOFs. Thus, even though economic benefits were produced as important means to justify the participation in the JOF, economic arguments were often strengthened with moral evaluation. In our opinion, this may stem from the variety of meanings attached with the forests and forest owning in Finland. As Finland is the most heavily forested country in Europe (FAO 2010), the forests have traditionally been an essential national economic asset. The important economic role of forests is also reflected in the national identity - connections to the forests often produce the important elements of the 'Finnish-ness' (Herman 2016). Given the importance of forests for Finns, the utilization of forests is, therefore, imbued with moral evaluations (Siiskonen 2007). Consequently, the active forest management has become a moral norm, and a "good forest owner" identity is based on the idea of fulfilling the moral obligation to take a proper care of the forest. Thus, the results of this study suggest that legitimation of new forest ownership forms, like JOFs, is not 
solely a process of rational and economic calculation for a forest owner but more likely a question concerning the moral evaluation of the new practices.

The examination of the legitimation strategies, particularly the moralization strategy, demonstrates how forest owners often create strong emotional bonds to their forest estates. The forests, particularly those inherited, are often produced as a means to identify the owner as a link in the chain of generations (e.g., Bliss and Martin 1989; Jörgensen and Stjernström 2008). This can reflect in their forest management as the owners consider themselves to be responsible for maintaining and transferring the forest as a legacy for the next generation. The idea of cherishing the forest as a legacy was strongly highlighted in the decision to join the JOF as well. Similar to Domínguez and Shannon (2011) who studied the factors influencing active forest management decisions, we found forest owning to include a moral norm to keep the family forests in the possession of the family in the best possible condition. According to Domínguez and Shannon (2011, p. 444) this moral norm can elicit powerful emotions as breaking or violating it would cause intense feeling of shame, while maintaining the norm gives sense of pride. In our opinion, the powerful normative nature related to the idea of forest as a legacy greatly explains the motivation of private forest owners to join the JOF and give up the control of their own forest.

Even though the emotional bond to the forest provides an important stimulus to join the JOF, the strong emotional attachments individual forest owners have may also create some challenges to the operation of the JOF. More specifically, even though joining the JOF means that the control of forest management decisions is transferred to a selected group of trustees, the feelings of psychological ownership towards the forest may still remain strong. Thus, it is important to understand that joining a JOF changes the very nature of forest ownership and one's existing identity as a forest owner. It has been claimed that identity transition processes usually involve loss-related emotions. In becoming a shareholder in a JOF, the forest owners lose the control over their forests — they cannot necessarily make any forest-related decision personally any more, nor any forest management activities. Thus, in a sense they lose their forest in exchange for shares in a JOF. The intensity of the loss-related emotions, like sadness, associated with the identity transformation is dependent on the felt distance between the old and new identities (Conroy and O'Leary-Kelly 2014). For example, for those forest owners who used to do forest work by themselves, the decision to become a shareholder in a JOF may create very strong loss-related emotions. Thus, it is essential to note that in legitimating the new institutional ownership practice of the jointly-owned forest, the forest owners are indeed 
simultaneously re-producing their new identities as jointly-owned forest shareholders. An important part of becoming a shareholder in a JOF is then to be able to build a valid identity narrative to explain why the change from the conventional forest owner practice to a JOF has occurred (see Conroy and O'Leary 2014). This was accomplished in the data through the legitimating accounts of authorization, moralization and rationalization. Accordingly, the authorization highlighted the forest owners' sense of autonomy when making decisions concerning the forest — in this case the decision to join the JOF - thus constructing themselves as autonomous decision-makers. Through moralization, the forest owners further constructed themselves as responsible owners making the necessary "sacrifices", i.e., losing control of their forests, in order to secure the interest of the next forest-owner generation as well as the forest itself. Finally, rationalization reinforces the identity narratives of active and informed forest owners by incorporating rationality as essential aspect of their decision to join the JOF.

The legitimation of a new kind of forest ownership uses the same kind of arguments that are used when legitimating forest management in general. These arguments are, at least implicitly, based on the idea of active forest owners who has a conscious approach to the forest holding and ownership and makes deliberate choices regarding how to utilize the forest area, even if letting others do the practical forest work (Follo 2011). For this reason, it is unsure whether this kind of legitimation actually appeals to the passive forest owner type even though at the policy discourse, JOFs are expected to provide one effective means to activate the indifferent and passive owners. Indeed, the majority of the forest owners in our data were also those who had been actively taking care of their forests. Accordingly, our results suggest that the decision to join the JOF was made in order to continue and guarantee active forest management as well in the future. The most of these active forest owners anticipated that the next generation would be more passive in their forest management — thus, in this sense, joining the JOF was their attempt to prevent passive forest management in their own family context. By using the current public legitimation, it may be more effective to focus on the active forest owners, who are afraid of the next forest generation being passive rather than target the passive forest owners. For them, some new kind of legitimation must be found.

\section{Conclusions}

The main objective of the national forest policy in Finland is to enhance the sustainable production of the material and immaterial benefits of the forests to serve the needs of all citizens (Valkeapää and Karppinen 
2013). This also requires effective and informed forest management among private forest owners who own over 60 per cent of the Finnish forest land (Statistical Yearbook of Forestry 2014). As the ownership structure is changing, along with the values of forest owners, developing new institutional ownership practices is seen as important in enhancing the national forest policy objectives. In this context, the question of legitimacy becomes essential - how is legitimacy discursively constructed into new, potential forest-ownership practices?

Van Leeuwen's model provides a useful theoretical tool to study the legitimation in the context of JOFs. Even though the model has been utilized in various contexts, in our best knowledge, it has not been used in the context of forest ownership previously. Although the discursive legitimation strategies presented in this study are context-specific in the sense that they are used to justify a certain type of forest ownership innovation in Finland, we nevertheless suggest that these legitimating strategies are also likely to characterize other institutional innovations in the forest-owning settings, as these innovations usually change the perceptions of ownership, and thus affect the forest-owner identities. Furthermore, we also suggest that it is important to see that in legitimizing new forest-related innovations, owners are often strongly influenced by the prevailing dominant macro-level discourses (e.g., Deci and Ryan 2008), particularly in this case, the national forest policy discourse, which has been effectively distributed to the owners through various information and extension services, as well as policies and legislation. The main characteristics of the Finnish Forest Policy stem from the important economic role forests play in the economy (Van Kooten et al. 1999). As a result, the policy decisions concerning forest use have traditionally emphasized increasing, though sustainable, timber production (Rantala and Primmer 2003). At the policy level, the legitimation for the forest management is thus usually based on the rationalization discourse. Consequently, by referring to the commonly-accepted policy discourse by constructing JOFs as an effective means to manage the forests for timber production, the forest owners simultaneously demonstrated that their untypical way of owning the forest is in line with the hegemonic forest-owning discourse.

It should be recalled, however, that legitimizing JOFs as new institutional practice among private forest owners did not solely reflect the macro-level policy discourse. Thus, while the national discourse is mainly based on the idea of rationality, by emphasizing the national economic benefits of timber production, the discursive strategies used by the micro-level forest owners were often imbued with a variety of values. The emotional values of forest ownership, i.e., the idea of as an intergenerational link and an emotional anchor to certain geographical area, strongly influenced the essence of the legitimation strategies particularly, and forest 
owners' decision-making processes more generally (see Grubbström 2011). In addition, it is important to recognize that during the legitimation process, the forest owners similarly reproduce their new identities. Thus, our study demonstrates that macro-level initiated changes in forest ownership cannot be motivated at the microlevel just by using economic incentives. Instead, in order to be successful, such institutional changes need to be supported by invoking emotional responses as well. For example, JOFs could profile themselves through different value promises to better meet the private forest owners' emotional needs. This could support the creation of JOFs to meet the needs of those forest owners not endorsing the economic values, while still enhancing the utilization of forest resources in general. The legislation should be flexible enough for this as well.

At the end, some limitations of the study must be addressed. Characteristic of the qualitative research aiming to understand the phenomenon in question, the empirical data in the study was also quite small (cf. Mason, 2010). Thus, we cannot, for example, claim which strategy is most often used to justify the decision to become a JOF shareholder. In order to make such claims, a larger sample with the ability to make statistical generalizations is needed. Furthermore, our data only consisted of those private forest owners who had made the decision to join the JOF and who were mainly active in their forest management. Future research could therefore broaden the approach to forest-owning innovation by addressing the arguments of those forest owners responding negatively to JOFs and who are passive in general on silvicultural decisions. Similarly, an interesting and important area for future research on JOFs would be exploring the link between the owners' objectives for their forests or demographic variables (like the age of the forest owner, the size of the forest holding etc.) to the willingness to join a JOF. This could, for example, further illustrate the need for the creation of JOFs with different value promises.

\section{References}

Act on Jointly-owned Forests (2003) Ministry of Agriculture and Forestry, Finland. https://www.finlex.fi/fi/laki/kaannokset/2003/en20030109.pdf. Accessed 18. February 2015

Alvesson, M Kärreman D (2000) Varieties of discourse: On the study of organizations through discourse analysis. Human Relations, 53:1125-1148 
Best C (2004) Non-governmental organizations: More owners and smaller parcels pose major stewardship challenges. Journal of Forestry 102:10-11

Bitektine A, Haack P (2015) The "macro" and the "micro" of legitimacy: Toward a multilevel theory of the legitimacy process. Academy of Management Review 40: 49-75

Bliss JC, Martin AJ (1988) Identity and private forest management. Society \& Natural Resources: An International Journal 1:365-376

Boon TE, Meilby H (2004) Relations between owner characteristics and forest ownership objectives. In: Baumgartner DM (ed) Proceedings of human dimensions of family, farm and community forestry international symposium. Pullman, WA, Washington State University, pp 75-79

Boon TE, Meilby H, Thorsen BJ (2004) An empirical based typology of private forest owners in Denmark: Improving communication between authorities and owners. Scandinavian Journal of Forest Research 19:45-55.

Butler BJ, Leatherberry EC (2004) America's family forest owners. Journal of Forestry 102:4-9

Conroy SA, O’Leary-Kelly AM (2014) Letting go and moving on: Work-related identity loss and recovery. Academy of Management Review 39:67-87

Creed WED, Scully MA, Austin JR (2002) Clothes make the person? The tailoring of legitimating accounts and the social construction of identity. Organization Science 13:475-496

Deci EL, Ryan RM (2008) Self-determination theory: A macrotheory of human motivation, development, and health. Canadian Psychology/Psychologie canadienne 49:182-185

Deephouse DL, Carter SM (2005) An examination of differences between organizational legitimacy and organizational reputation. Journal of Management Studies 42:329-360

Domínguez G, Shannon M (2011) A wish, a fear and a complaint: Understanding the (dis)engagement of forest owners in forest management. European Journal of Forest Research 130:435-450

Dowling J, Pfeffer J (1975) Organizational legitimacy. Pacific Sociological Review 18: 122-36 
Eisenhardt K.M (1989) Building theories from case study research. Academy of Management Review 14: 532550

Erkama N, Vaara E (2010) Struggles over legitimacy in global organizational restructuring: A rhetorical perspective on legitimation strategies and dynamics in a shutdown case. Organization Studies 31: 813-839

Fairclough N (2003) Analyzing discourse: Textual analysis for social research. Routledge, London

FAO (2010) The Global Forest Resources Assessment 2010 (FRA 2010). Main report. FAO Forestry paper 163. Food and Agriculture Organization of United Nations. Rome, 2010

Follo G (2011) Factors influencing Norwegian small-scale private forest owners' ability to meet the political goals. Scandinavian Journal of Forest Research 26:385-393

Grubbström A (2011) Emotional bonds as obstacles to land sale: Attitudes to land among local and absentee landowners in Northwest Estonia. Landscape and Urban Planning 99:31-39

Havia P (2012) Yhteismetsä. Perustaminen, hallinto, verotus. Metsätalouden kehittämiskeskus Tapio, Helsinki.

Herman A (2016) 'More-than-human' resilience (s)? Enhancing community in Finnish forest farms. Geoforum 69: $34-43$

Horne P (2006) Forest owners' acceptance of incentive based policy instruments in forest biodiversity conservation: A choice experiment based approach. Silva Fennica 40:169-178

Hugosson M, Ingemarsson F (2004) Objectives and motivations of small-scale forest owners: Theoretical modelling and qualitative assessment. Silva Fennica 38:217-231

Hujala T, Pykäläinen J, Tikkanen J (2007) Decision making among Finnish nonindustrial private forest owners: The role of professional opinion and desire to learn. Scandinavian Journal of Forest Research 22:454-463

Hujala T, Tikkanen J (2008) Boosters of and barriers to smooth communication in family forest owners' decision making. Scandinavian Journal of Forest Research 23:466-477 
Hutchby I (2001) 'Witnessing': The use of first-hand knowledge in legitimating lay opinions on talk radio.

Discourse Studies 3:481-497

Hänninen, H, Karppinen H, Leppänen J (2011) Suomalainen metsänomistaja 2010. Metlan työraportteja: 208.

Ingemarsson F, Lindhagen A, Eriksson L (2006) A typology of small-scale private forest owners in Sweden. Scandinavian Journal of Forest Research 21:249-259

Jörgensen H, Stjernström O (2008) Emotional links to forest ownership. Restitution of land and use of a productive resource in Põlva County, Estonia. Fennia 2: 95-111.

Karppinen H, Tiainen L (2010) "Semmonen niinku metsäkansa”: Suurten ikäluokkien perijät tulevaisuuden metsänomistajina ["Kind of forest people": Inheritors of the postwar baby-boom generation as the future forest owners]. Metsätieteen Aikakauskirja 1:19-38

Kilgore MA, Greene JL, Jacobson MG, Straka TJ, Daniels SE (2007) The influence of financial incentive programs in promoting sustainable forestry on the nation's family forests. Journal of Forestry 105:184-191

Korhonen V (2010) Forest land consolidations and jointly-owned forests: The way towards better forestry competitiveness. FIG Congress 2010, Sydney, Australia, 11-16 April

Kotilainen J, Rytteri T (2011) Transformation of forest policy regimes in Finland since the 19th century. Journal of Historical Geography 37:429-439

Kline JD, Alig RJ, Johnson RL (2000) Fostering the production of non-timber services among forest owners with heterogeneous objectives. Forest Science 46(2):302-311

Kuuluvainen J, Karppinen H, Ovaskainen V (1996) Landowner objectives and nonindustrial private timber supply. Forest Science 42:300-309

Legard R, Keegan J, Ward K (2003) In-depth interviews. In Ritchie, J. and Lewis, J., Editors, 2003. Qualitative research practice: A guide for social science students and researchers, Sage, Thousand Oaks, CA.

Leppänen J (2010) Finnish family forest owner 2010 survey. In: Helles F, Nielsen PS (eds) Scandinavian forest economics 43. Proceedings of the Biennial Meeting of the Scandinavian Society of Forest 
Economics, $\quad$ Gilleleje, $\quad$ Denmark, $\quad$ May 2010, pp184-195. http://www.metla.fi/org/ssfe/publications/Scandinavian_Forest_Economics_No_43.pdf Accessed 26 March 2015

Leppänen J, Sevola Y (2014) Metsämaan omistus 2012. Metsätilastotiedote 6/2014. Metsäntutkimuslaitos. http://www.metla.fi/metinfo/tilasto/julkaisut/mtt/2014/metsamaan_omistus2012.pdf. Accessed 29 July 2015

Leppänen J, Torvelainen J (2015) Tilasto. Metsämaan omistus 2013. Luonnonvarakeskus, Helsinki.

Lidestav G (1998) Women as non-industrial private forest landowners in Sweden. Scandinavian Journal of Forest Research 13: 66-73

Lönnstedt L (2012) Small Scale Forest Owners' Responsibilities: Results from a Swedish Case Study. Smallscale Forestry 11: 407-416

Mason M (2010) Sample size and saturation in PhD studies using qualitative interviews. Forum: Qualitative Social Research 11:1-17

Matilainen J (2009) Yhteismetsä: Hyvä ja tuottava metsänomistusmuoto. http://www.tapio.fi/files/tapio/Aineistopankki/Yhteismetsasta_perustietoa_Matilainen.pdf Accessed 15 May 2014

Ministry of Agriculture and Forestry (2012) Metsätilakoon ja rakenteen kehittäminen- Työryhmän loppuraportti. Työryhmämuistio MMM 2012:1. Helsinki 2012

Metsäkeskus (2015) http://www.metsakeskus.fi/sites/default/files/yhteismetsaluettelo_syyskuu_01092015_0.pdf Accessed 13 January 2016

Meyer JW, Rowan B (1977) Institutionalized organizations: Formal structure as myth and ceremony. The American Journal of Sociology 83:340-363

Ní Dhubháin Á, Cobanova R, Karppinen H, Mizaraite D, Ritter E, Slee B, Wall S (2007) The values and objectives of private forest owners and their influence on forestry behaviour: The implications for entrepreneurship. Small-Scale Forestry 6:347-357 
Patton MQ (2002) Qualitative research \& evaluation methods, 3rd edn. Sage, Thousand Oaks

Phillips, N, Hardy C (2002) Discourse analysis: Investigating processes of social construction. Thousand Oaks, CA: Sage.

Rantala T, Brimmer E (2003) Value positions based on forest policy stakeholders' rhetoric in Finland. Environmental Science \& Policy 6:205-216

Reyes A (2011) Strategies of legitimization in political discourse: From words to action. Discourse \& Society 22:781-807

Ritchie J, Spencer L, O’Connor, W. 2003. Carrying out qualitative analysis. In Ritchie, J. and Lewis, J. (eds.) Qualitative research practice. A guide for social science students and researchers. Thousand Oaks, Sage. 219-263.

Rojo LM, Van Dijk T (1997) “There is a Problem, and It was Solved!": Legitimating the Expulsion of "Illegal" Migrants in Spanish Parliamentary Discourse. Discourse \& Society 8:523-66

Rämö A-K, Tilli T (2007) Private forest owners' views on forms of co-ownership of forests in Finland. Pellervo Economic Research Institute Reports, No. 204

Scott WR (1995) Institutions and organizations. Sage, Thousand Oaks, Ca

Siiskonen H (2007) The conflict between traditional and scientific forest management in 20th century Finland. Forest Ecology and Management 249: 125-133

Statistical Yearbook of Forestry (2014) Finnish Forest Research Institute.

Steffek J (2009) Discursive legitimation in environmental governance. Forest Policy and Economics 11:313-318

Suchman MC (1995) Managing legitimacy: Strategic and institutional approaches. Academy of Management Review 20:571-611

Suddaby R, Greenwood R (2005) Rhetorical strategies of legitimacy. Administrative Science quarterly 50:35-67 Suomen metsät (2012) http://www.metla.fi/metinfo/kestavyys/c6-forest-holdings.htm Accessed 13 January 2016 
Thomsen S (2006) Industrial foundations: Foundation ownership of business companies. In: Prewitt K, Dogan

M, Heydemann S, Toepler S (eds) Legitimacy of philanthropy foundations: United States and European perspectives. Russell Sage Foundation, pp 236-251

Tikkanen J, Isokääntä T, Pykäläinen J, Leskinen P (2006) Applying cognitive mapping approach to explore the objective-structure of forest owners in a Northern Finnish case area. Forest Policy and Economics, 9:139-152

Vaara E (2014) Struggles over legitimacy in the Eurozone crisis: Discursive legitimation strategies and their ideological underpinnings. Discourse \& Society 25:500-518

Vaara E, Tienari J, and Laurila J (2006) Pulp and paper fiction: On the discursive legitimation of global industrial restructuring. Organizational Studies 27:789-810

Valkeapää A, Karppinen H (2013) Citizens' view of legitimacy in the context of Finnish forest policy. Forest Policy and Economics 28:52-59

Van Dijk TA (1998) Ideology. A multidisciplinary approach. Sage, London

Van Kooten GC, Vertinsky I, Wilson B (1999) Finland. In: Wilson B, Van Kooten GC, Vertinsky I, Arthur L (eds) Forest policy: International case studies. CABI Publishing, pp 187-214

Van Leeuwen T (2007) Legitimation in discourse and communication. Discourse \& Communication, 1:91-112.

Van Leeuwen T, Wodak R (1999) Legitimizing immigration control. A discourse \pm historical analysis. Discourse Studies 1: 83-118

Vergne J-P, Wry T (2014) Categorizing categorization research: Review, integration, and future directions. Journal of Management Studies 51:56-94

Zimmerman MA, Zeitz GJF (2002) Beyond survival: Achieving new venture growth by building legitimacy. Academy of Management Review 27:414-431 
Tables:

\begin{tabular}{|c|c|}
\hline $\begin{array}{l}\text { The main themes of the } \\
\text { interviews }\end{array}$ & Examples of the questions used to prompt the discussion \\
\hline $\begin{array}{l}\text { Personal forest owning } \\
\text { history }\end{array}$ & $\begin{array}{l}\text { What kind of a forest do you own? } \\
\text { What are your main values as a forest owner? } \\
\text { What kind of objectives do you have for your forest management? }\end{array}$ \\
\hline $\begin{array}{l}\text { The motivation for } \\
\text { becoming a JOF shareholder }\end{array}$ & $\begin{array}{l}\text { How did you get to know the idea of a JOF? } \\
\text { What did motivate you to join the JOF? } \\
\text { What were the main doubts you had concerning the JOF? } \\
\text { With whom did you discuss the decision to join the JOF? } \\
\text { Did the opinions of family members/other forest owners influence your } \\
\text { decision-making? }\end{array}$ \\
\hline $\begin{array}{l}\text { Experiences of the JOF } \\
\text { establishment process }\end{array}$ & How did you feel the process of establishing the JOF? \\
\hline $\begin{array}{l}\text { Experiences of the operation } \\
\text { of the JOF }\end{array}$ & $\begin{array}{l}\text { How satisfied are you with the operation of the JOF? (the economic income, the } \\
\text { ability to influence the decisions, the way the JOF is managed) } \\
\text { Whom did you recommend the participation in the JOF and why? }\end{array}$ \\
\hline The changing identity & $\begin{array}{l}\text { Do you still visit the forests you invested in the JOF? } \\
\text { How is your identity as a forest owner changed after joining the JOF? }\end{array}$ \\
\hline
\end{tabular}

Table 1. Themes used in the research interviews

\begin{tabular}{|c|c|c|c|c|}
\hline & $\begin{array}{l}\text { "Age" of the } \\
\text { forest owner }\end{array}$ & $\begin{array}{l}\text { The way of becoming a } \\
\text { forest owner }\end{array}$ & $\begin{array}{l}\text { Forest area } \\
\text { invested in the JOF } \\
\text { (the share of all the } \\
\text { forest area) }\end{array}$ & $\begin{array}{l}\text { "Distance to the } \\
\text { forest" (i.e. whether } \\
\text { the forest owner lives } \\
\text { in the JOF area) }\end{array}$ \\
\hline 1 & pensioner & $\begin{array}{c}\text { inheritance+purchase on } \\
\text { external markets }\end{array}$ & $40(57 \%)$ & local \\
\hline 2 & pensioner & inheritance & n.a. & local \\
\hline 3 & working age & $\begin{array}{l}\text { inheritance+purchase on } \\
\text { external markets }\end{array}$ & $3(4 \%)$ & local \\
\hline 4 & working age & inheritance & 13 (n.a.) & local \\
\hline 5 & pensioner & inheritance & 4 (n.a.) & non-local \\
\hline 6 & pensioner & $\begin{array}{c}\text { inheritance+purchase on } \\
\text { external markets }\end{array}$ & $7(41 \%)$ & non-local \\
\hline 7 & pensioner & inheritance & $50(100 \%)$ & local \\
\hline 8 & pensioner & inheritance & $15(60 \%)$ & non-local \\
\hline 9 & pensioner & inheritance & $5(100 \%)$ & non-local \\
\hline 10 & working age & $\begin{array}{l}\text { inheritance+purchase on } \\
\text { external markets }\end{array}$ & $70(32 \%)$ & local \\
\hline 11 & pensioner & $\begin{array}{c}\text { purchase on external } \\
\text { markets }\end{array}$ & 10 (n.a.) & local \\
\hline 12 & working age & $\begin{array}{l}\text { purchase on external } \\
\text { markets }\end{array}$ & $36(72 \%)$ & local \\
\hline 13 & working age & $\begin{array}{c}\text { inheritance+purchase on } \\
\text { external markets }\end{array}$ & $10(10 \%)$ & local \\
\hline 14 & pensioner & inheritance & $29(83 \%)$ & local \\
\hline 15 & working age & inheritance & $6(100 \%)$ & non-local \\
\hline 16 & working age & inheritance & n.a. & non-local \\
\hline 17 & working age & inheritance & $15(100 \%)$ & non-local \\
\hline 18 & pensioner & $\begin{array}{l}\text { inheritance+purchase on } \\
\text { external markets }\end{array}$ & $10(33 \%)$ & local \\
\hline 19 & working age & $\begin{array}{l}\text { inheritance+purchase on } \\
\text { external markets }\end{array}$ & n.a. & local \\
\hline 20 & working age & inheritance & $15(100 \%)$ & non-local \\
\hline
\end{tabular}

Table 2. Background information on the forest owners interviewed 


\begin{tabular}{|l|l|l|}
\hline $\begin{array}{l}\text { Legitimation } \\
\text { strategy }\end{array}$ & $\begin{array}{l}\text { How is the strategy constructed? } \\
\text { Authorization }\end{array}$ & $\begin{array}{l}\text { Why is the strategy effective in } \\
\text { increasing the legitimacy of the JOFs? }\end{array}$ \\
\hline $\begin{array}{l}\text { Legitimating JOFs based on the forest } \\
\text { owners' own or others' knowledge and } \\
\text { expertise (media, forest advisors, } \\
\text { municipality)or based on traditions }\end{array}$ & $\begin{array}{l}\text { Legitimation through authorization } \\
\text { honours the forest owner's sense of } \\
\text { autonomy when making decisions } \\
\text { concerning the forest }\end{array}$ \\
\hline Moralization & $\begin{array}{l}\text { Legitimating JOFs based on emotions by } \\
\text { emphasizing the moral responsibility one } \\
\text { has towards the forests }\end{array}$ & $\begin{array}{l}\text { Legitimation through moralization } \\
\text { reinforces/constructs the identity of a } \\
\text { moral forest owner who maintains the } \\
\text { well-being of the forest as well as the next } \\
\text { forest-owner generation }\end{array}$ \\
\hline Rationalization & $\begin{array}{l}\text { Legitimating JOFs based on instrumental } \\
\text { benefits by emphasizing the economic } \\
\text { and personal utilities that derive from } \\
\text { joining a JOF }\end{array}$ & $\begin{array}{l}\text { Legitimation through rationalization } \\
\text { highlights the idea that the loss of control } \\
\text { over one's forest area is well } \\
\text { compensated }\end{array}$ \\
\hline
\end{tabular}

Table 3. Summary of the main research results 